\title{
Modelling auto ignition of hydrogen in a jet ignition pre-chamber
}

\author{
Alberto A. Boretti \\ School of Science and Engineering, University of Ballarat, PO Box 663, Ballarat, Victoria 3353, Australia
}

\section{A R T I C L E I N F O}

Article history:

Received 20 November 2009

Received in revised form

25 January 2010

Accepted 26 January 2010

Available online $\mathrm{xxx}$

Keywords:

Gas engines

Direct injection

Jet ignition

Auto ignition

Lean burn stratified combustion

Bulk ignition and combustion

\begin{abstract}
A B S T R A C T
Spark-less jet ignition pre-chambers are enablers of high efficiencies and load control by quantity of fuel injected when coupled with direct injection of main chamber fuel, thus permitting always lean burn bulk stratified combustion. Towards the end of the compression stroke, a small quantity of hydrogen is injected within the pre-chamber, where it mixes with the air entering from the main chamber. Combustion of the air and fuel mixture then starts within the pre-chamber because of the high temperature of the hot glow plug, and then jets of partially combusted hot gases enter the main chamber igniting there in the bulk, over multiple ignition points, lean stratified mixtures of air and fuel. The paper describes the operation of the spark-less jet ignition pre-chamber coupling CFD and $\mathrm{CAE}$ engine simulations to allow component selection and engine performance evaluation. (c) 2010 Professor T. Nejat Veziroglu. Published by Elsevier Ltd. All rights reserved.
\end{abstract}

\section{Introduction}

The hydrogen fuelled internal combustion engine is now receiving large attention because of the opportunity operating lean of stoichiometry $(\lambda>2.25)$ to achieve top brake efficiencies over $45 \%$ while permitting below EURO 6 emissions without any after treatment [1-10]. Direct fuel injection and turbo charging are two common features of advanced $\mathrm{H}_{2}$-ICE. The always lean burn direct injection jet ignition (DI-JI) engine proposed by the author also uses jet ignition as a third distinctive feature. The main chamber combustion is not produced by a low energy spark discharge in a single location close to the combustion chamber walls, but by multiple jets of high energy, hot partially burned, reacting gases issued from a small pre-chamber and travelling all over the combustion chamber. Jet ignition permits more complete combustion of much leaner mixtures, plus ignition and combustion of lean stratified mixtures in the bulk, thus reducing heat losses to the walls. The always lean burn direct injection jet ignition engine is aimed to further increase top brake efficiencies as well as to reduce the efficiency penalty changing the load for a Diesellike operation by quantity of fuel injected enabled by the option to burn fuel mixtures extremely lean [11-16].

The jet ignition device is made up of a pre-chamber, connected to the main chamber through calibrated orifices, accommodating a pre-chamber DI fuel injector. In the standard spark plug version [11-16], the jet ignition device also includes a spark plug that ignites a pre-chamber mixture slightly rich that then bulk ignites the ultra lean, stratified main chamber mixture through the multiple jets of hot reacting gases entering the in-cylinder. Fig. 1 presents a sectional view of the in-cylinder and pre-chamber volumes of the DI-JI engine in the spark plug version (from Ref. [16]). The jet ignition device is a $1.5 \mathrm{~cm}^{3}$ multiple nozzle type featuring 6 equally spaced nozzles of diameter $1.25 \mathrm{~mm}$. Details of the direct injectors to main and pre-chamber are not included. In the glow plug

E-mail address: a_boretti@yahoo.com 0360-3199/\$ - see front matter @ 2010 Professor T. Nejat Veziroglu. Published by Elsevier Ltd. All rights reserved. doi:10.1016/j.ijhydene.2010.01.114 


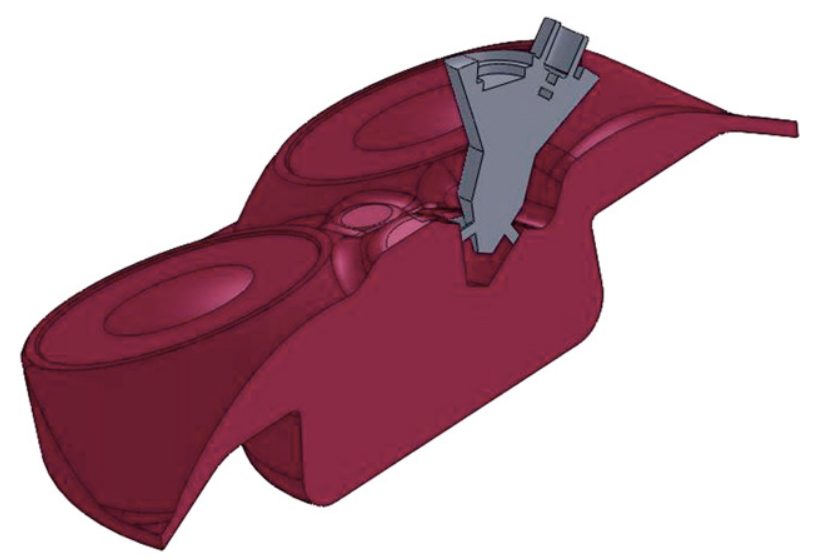

Fig. 1 - Plane cut of the in-cylinder and pre-chamber volumes (from [16]).

version considered here, the spark plug is replaced by a glow plug to increase durability and reduce maintenance costs, improve packaging and avoid occurrence of locally fuel rich conditions reducing the formation of nitrogen oxides. In the glow plug version, an even smaller amount of fuel is injected in an even smaller pre-chamber $1 \mathrm{~cm}^{3}$ and then auto ignites after impinging on the hot glow plug surface that keeps the temperature within the pre-chamber very high. Fuel is injected directly within the cylinder by the main chamber DI injector operating single or multiple injections to produce a lean stratified mixture. This non homogeneous mixture is mildly lean $(\lambda=1.5-2.25)$ in an inner region surrounded by air and some residuals from the previous cycle. The extension of the inner region is reduced in size to achieve mean chamber average mixtures ranging from slightly lean to extremely lean $(\lambda=2.25$ to $\lambda=7)$. This mixture is then ignited by jets of reacting gases that issue from the pre-chamber.

With reference to homogeneous DI or port fuel injection (PFI) and main chamber spark ignition, non homogeneous DI and jet ignition offer the advantage of much faster, more complete, much leaner combustion, less sensitivity to mixture state and composition, and reduced heat losses to the main chamber walls. This is because of better fuel-to-air ratio of the combusting mixture for same chamber averaged lean conditions, combustion in the bulk of the in-cylinder gases, heat transfer cushion of air between hot reacting gases and walls, very high ignition energy, multiple simultaneous ignition sites igniting the bulk of the in-cylinder gases, and large concentrations of partially oxidized combustion products initiated in the pre-chamber accelerating the oxidation of fresh reactants.

Aim of the paper is to couple Computational fluid dynamic (CFD) and Computer Aided Engineering (CAE) engine performance simulations to describe the operation of the spark-less jet ignition pre-chamber. CFD simulations will be used to study the mixture formation within the pre-chamber and the main chamber, the auto ignition process within the prechamber, and the subsequent jet ignition of the main chamber mixture and the combustion evolution within the main chamber. These descriptions will permit selection of direct injectors to main chamber and pre-chamber and glow plug, set-up of injection timings and flow profiles for injectors, and definition of time scales of heat release processes within pre-chamber and main chamber needed in CAE simulations of engine performances. The combustion processes are strongly influenced by both chemical kinetics and averaged and turbulent transport and diffusion. Therefore, CFD simulations must properly couple turbulence and chemical kinetics. CFD simulations of the influence of chemical kinetics and averaged and turbulent transport and diffusion are presented in [17-22], coupling linear-eddy models (LEM) [19] or Direct Numerical Simulation (DNS) [20,21] with detailed chemistry libraries. Considering the complexity of the flow field, with details of geometry and initial and boundary conditions being much more important than the modelling of turbulence, Reynolds-Averaged Navier-Stokes (RANS) equations are preferred to DNS, while chemistry is considered detailed.

\section{Direct injector selection}

The amount of fuel to be introduced by the direct injector within the pre-chamber is quite small. If $V_{P C}$ is the prechamber volume, $\mathrm{V}_{\mathrm{MCC}}$ is the main chamber combustion chamber volume and $V_{D}$ the displaced volume, $V_{D}=\pi \cdot B^{2} / 4 S$, with $B$ the bore and $S$ the stroke of the engine, the true compression ratio of the engine is $C R=\left(V_{P C}+V M C C+V_{D}\right) /$ $\left(V_{\mathrm{PC}}+\mathrm{V}_{\mathrm{MCC}}\right)$, while the reference compression ratio is $\mathrm{CR}^{*}=\left(\mathrm{V}_{\mathrm{MCC}}+\mathrm{V}_{\mathrm{D}}\right) /\left(\mathrm{V}_{\mathrm{MCC}}\right)$. If $\eta_{\mathrm{V}}$ is the volumetric efficiency $\eta_{\mathrm{V}}=\left(m_{\mathrm{a}}\right) /\left(\rho_{\mathrm{a}, \mathrm{i}} \cdot \mathrm{V}_{\mathrm{D}}\right)$, where $m_{\mathrm{a}}$ is the mass of air trapped within the cylinder when the intake valves close and $\rho_{\mathrm{a}, \mathrm{i}}$ is the reference air density, then the mass of fuel to be injected within the pre-chamber is:

$m_{\mathrm{f}, \mathrm{PC}}=\left[\frac{(\mathrm{F} / \mathrm{A})_{\mathrm{s}}}{\lambda_{\mathrm{PC}}}\right] \cdot \eta_{\mathrm{V}} \cdot \rho_{\mathrm{a}, \mathrm{i}} \cdot(\mathrm{CR}-1) \cdot \mathrm{V}_{\mathrm{PC}}$

where $(F / A)_{s}$ is the stoichiometric fuel-to-air ratio, and $\lambda_{\mathrm{PC}}$ is the pre-chamber operational air-to-fuel equivalence ratio. $\eta_{\mathrm{V}}$ is about unity for naturally aspirated engines, but can reach values up to 2 in highly turbocharged versions with charge cooler, while CR may range from 10:1 to $15: 1$ depending on the boost provided by the turbo charger, and $(F / A)_{s}$ is 0.0294 for $\mathrm{H}_{2}$.

In the spark plug version, all the pre-chamber fuel has to be introduced before the spark discharge starts combustion, $\lambda_{\mathrm{PC}}$ is representative of the fuel-to-air ratio at the start of combustion, and values slightly smaller than unity (i.e. slightly fuel rich) provide the best results. In the glow plug version, auto ignition starts before all the fuel is injected, and $\lambda_{\mathrm{PC}}$ is now just representative of the total fuel that will be injected within the pre-chamber. This parameter may reach values $\lambda_{\mathrm{PC}}=2-3$. Therefore, the pre-chamber DI injector has to introduce less fuel than the main chamber DI injector in general, and this amount is less in the glow plug vs. the spark plug version. In case of a turbocharged engine with unit displacement $375 \mathrm{~cm}^{3}$, compression ratio $14.5: 1$, volumetric efficiency 1.9, pre-chamber volume $1.5 \mathrm{~cm}^{3}$, the mass of hydrogen fuel to be introduced within the pre-chamber for stoichiometric conditions is $1.3 \mathrm{mg}$, and in case of a naturally aspirated engine with unit displacement $600 \mathrm{~cm}^{3}$, compression ratio $11: 1$, volumetric efficiency 1 , pre-chamber volume $1.5 \mathrm{~cm}^{3}$ it is $1 \mathrm{mg}$. 
The auto ignition process set constraints to the injector pulse width duration and therefore to the flow rate and the opening and closing times. In the spark plug version, injection has to be completed before the spark discharge ignites the prechamber mixture, and it may start almost any time during the compression stroke and it may have almost any duration. In the glow plug version, fuel injection has to be faster with much higher flow rates to be effective. Enough fuel has to be introduced before the combustion evolution within the prechamber will increase there the pressure up to the very high values that will finally force the hot partially combusted products and radicals to move towards the main chamber. In the glow plug version, even if the quantity of fuel injected is much smaller, the flow rate has to be much larger and the opening times much shorter than in the spark plug version. During the injection time, the nozzles are very unlikely to be choked, because the needle lift is opening and closing, with the minimum area being very likely the needle seat area over the most part of the injection process.

A proper estimation of the ignition delay is central to the development of the auto ignition glow plug pre-chamber. Published measured data obtained in shock tubes or rapid compression machines experiments [23-25] only partially help because not only composition, pressure and temperature differ, but also averaged and turbulent transport and diffusion are different. As a rough guideline, the auto ignition time is given in [25] as follows:

$\tau_{\text {ign }}=\mathrm{A} \cdot\left[\mathrm{X}_{\mathrm{H}_{2}}\right]^{\mathrm{x}} \cdot \phi^{y} \cdot p^{z} \cdot \exp [\mathrm{E} / \mathrm{RT}]$

where $\tau_{\text {ign }}$ is the ignition delay time, $\mathrm{X}_{\mathrm{H}_{2}}$ the $\mathrm{H}_{2}$ mole fraction in the overall fuel-air mixture, $\varphi$ the fuel-to-air equivalence ratio, $p$ is the pressure, $T$ the temperature, $R$ the gas constant and $E, A, x, y$, and $z$ are model constants. This equation provides auto ignition times of about $0.2 \mathrm{~ms}$ with $p=1$ bar, $\mathrm{T}=1000 \mathrm{~K}, \varphi=0.5$, that are well below the time for complete opening and closure of today's fastest GDI piezo injectors that require times to achieve full opening lifts of about $0.04 \mathrm{~mm}$ of not less than $0.3 \mathrm{~ms}$. On the other hand, these injectors can also be operated part lift, with reduced pulse width and flow rates, having the minimum flow area the choked needle seat area.

Injectors should operate with not less than 200 bar of pressure. The hydrogen gas flows from an upstream higher stagnation pressure to a much lower downstream pressure is choked in the minimum effective area. Assuming ideal gas behavior, steady state choked flow occurs when the ratio of the absolute upstream pressure to the absolute downstream pressure is equal to or greater than $[(k+1) / 2]^{k /(k-1)}$, where $k$ is the specific heat ratio of the gas. The equation for the mass flow rate per unit effective area is:

$\dot{m} *=\frac{\dot{m}}{A_{e}}=\sqrt{k \cdot p_{0} \cdot \rho_{0} \cdot\left[\frac{2}{(k+1)}\right]^{(k+1) /(k-1)}}$

where $\rho_{0}$ is the upstream stagnation density, $p_{0}$ the upstream stagnation pressure and $A_{e}$ is the effective throat area (product of geometrical area and flow coefficient). For hydrogen at $2 \cdot 10^{7} \mathrm{~Pa}$ of pressure and $300 \mathrm{~K}$ of temperature, we may assume $\rho_{0}=14.4 \mathrm{~kg} / \mathrm{m}^{3}, c_{\mathrm{v}}=20.857 \mathrm{~J} /(\mathrm{mol} \mathrm{K}), c_{\mathrm{p}}=29.658 \mathrm{~J} /$ $(\mathrm{mol} \mathrm{K}), \quad k=c_{\mathrm{p}} / \mathrm{c}_{\mathrm{v}}=1.422$ and therefore $\dot{m} *=1.17 \mathrm{E}+04 \mathrm{~kg} /\left(\mathrm{s} \mathrm{m}^{2}\right)$ or $11.7 \mathrm{~g} / \mathrm{s} \mathrm{mm}^{2}$, i.e. a flow rate of $4.09 \mathrm{~g} / \mathrm{s}$ with a minimum effective area of $0.35 \mathrm{~mm}^{2}$.

Equations (1)-(3) set constraints on pulse width and flow rate that suggest testing of fast actuating high pressure GDI injectors [26,27] or specific hydrogen injectors [28] as the potential pre-chamber direct injector.

\section{Computational model details}

Computations have been performed by using CFD and CAE engine performance tools, simulating detailed fluid dynamic and combustion phenomena within the pre-chamber and the in-cylinder and full cycle engine operation respectively. CFD simulations are performed by using STAR-CCM [29], while CAE simulations are performed by using GT-POWER [30]. Detailed chemistry is required to address many important issues, including ignition, auto ignition, knock, emission controls, fuel flexibility and exhaust gas recirculation. Challenges for using detailed kinetics are complexity of real fuels, scarcity of validated detailed mechanisms, simulations more timeconsuming. Coupling of STAR-CCM code with a chemical package [31,32] is the option selected to simulate mixture formation, auto ignition and combustion thus enabling user to focus on the application rather that in the details of chemistry or turbulence or numeric.

Detailed kinetics schemes for hydrogen and air mixtures are proposed in [34-36]. Reaction-rate parameters are given for the detailed chemistry of gas-phase hydrogen combustion, involving 21 reversible elementary steps in [34]. It is indicated that, when attention is restricted to specific combustion processes and particular conditions of interest, fewer elementary steps are needed. In particular, for calculating auto ignition times over a wide range of pressures for temperatures between about 1000 and $2000 \mathrm{~K}$, five irreversible elementary steps suffice, yielding a remarkable reduction in complexity. It is explained that, from a mathematical viewpoint, in terms of global reaction-kinetic mechanisms, the hydrogen-oxygen system in principle comprises only six overall steps. Rational reduced chemical mechanisms for hydrogen combustion therefore necessarily must have fewer than six overall steps. For auto ignition over the range of conditions specified above, ignition times can be determined accurately by considering, in addition to an elementary initiation step and an elementary termination step, at most three overall steps for reaction intermediaries, which reduce to two for very fuel-lean conditions and to one for stoichiometric or fuel rich conditions. The resulting reductions can simplify computations that need to be performed in risk analyses for hydrogen storage and utilization. A 21 elementary step mechanism is used in [35]. Particular attention is paid there to different channels of reaction between $\mathrm{H}$ atoms and $\mathrm{HO}_{2}$ radicals, to pressure dependence of the recombination of $\mathrm{HO}_{2}$ radicals, and to the anomalous rate constant of reaction between $\mathrm{OH}$ and $\mathrm{HO}_{2}$ radicals. A detailed kinetic mechanism is finally presented in [36] to simulate the combustion of $\mathrm{H}_{2} / \mathrm{O}_{2}$ mixtures, over a wide range of temperatures, pressures, and equivalence ratios.

Kinetics equations are obtained by using DARS-CFD [33]. The kinetics equations of the 21 elementary step mechanism 
used here are presented in Table 1. A, $n$ and $E_{a}$ are the Arrhenius rate constants:

$k=\mathrm{A} \cdot \mathrm{T}^{n} \cdot e^{-E_{\mathrm{a}} / \mathrm{RT}}$

The flow is considered turbulent, compressible, reacting, multi species. Turbulence is modeled by using a ReynoldsAveraged Navier-Stokes (RANS) turbulence model, in particular a 2 equations $\mathrm{K}-\varepsilon$ model with a two layer all $\mathrm{y}+$ wall treatment [29]. The $\mathrm{K}-\varepsilon$ RANS is preferred for simplicity, generality and reliability.

Transport and diffusion equations are solved for the nine chemical species, namely for $\mathrm{O}_{2}, \mathrm{H}_{2}, \mathrm{H}_{2} \mathrm{O}, \mathrm{H}, \mathrm{O}, \mathrm{OH}, \mathrm{HO}_{2}, \mathrm{H}_{2} \mathrm{O}_{2}$. STAR-CCM solves the Partial Differential Equations (PDEs) for energy and species conservation [29]:

$$
\begin{aligned}
& \frac{\partial}{\partial t} \rho Y_{k}+\frac{\partial}{\partial x_{j}}\left(\rho \cdot u_{j} \cdot Y_{k}+F_{k, j}\right)=0 \\
& \frac{\partial}{\partial t} \rho h+\frac{\partial}{\partial x_{j}}\left(\rho \cdot u_{j} \cdot h+F_{h, j}\right)=\frac{\partial}{\partial t} p+u_{j} \cdot \frac{\partial}{\partial x_{j}} p+\tau_{i, j} \cdot \frac{\partial}{\partial x_{j}} u_{i}
\end{aligned}
$$

While DARS-CFD solves the Ordinary Differential Equations (ODEs) for chemical kinetics [33]:

$\frac{\partial}{\partial t} Y_{i}=\frac{\omega_{i} \cdot W_{i}}{\rho}$

When chemical kinetics is the limiting factor of the reacting system under investigation, near-perfect mixing of reactants and products is usually achieved. However, normally these mixing mechanisms have to rely on fluid motion or largescale eddies and turbulence to provide the mixing. Local turbulence is particularly important as it promotes microscale mixing among the gas species. If the turbulence is too weak to provide fast mixing among the gas species, the micromixing process will interfere with the chemical kinetics. The previous model addresses both situations. Turbulence intensity is supposed to affect combustion through the Kong-Reitz model [32]:

Table 1 - DARS Preprocessor $\mathrm{H}_{2} / \mathrm{O}_{2}$ kinetic mechanism (units are $\mathrm{cm}^{3} \mathrm{~mol} \mathrm{~s} \mathrm{cal} \mathrm{K}$ ).

\begin{tabular}{|c|c|c|c|c|}
\hline & & \multicolumn{3}{|c|}{ H1H } \\
\hline & & A & $N$ & $E_{\mathrm{a}}$ \\
\hline r1f & $\mathrm{H}_{2}+\mathrm{O}_{2}=2 \mathrm{OH}$ & $1.700 \mathrm{E}+13$ & $0.000 \mathrm{E}+00$ & $1.999 \mathrm{E}+02$ \\
\hline $\mathrm{r} 1 \mathrm{~b}$ & $\mathrm{H}_{2}+\mathrm{O}_{2}=2 \mathrm{OH}$ & $2.223 \mathrm{E}+10$ & $3.877 \mathrm{E}-01$ & $1.202 \mathrm{E}+02$ \\
\hline $\mathrm{r} 2 \mathrm{f}$ & $\mathrm{H}_{2}+\mathrm{OH}=\mathrm{H}_{2} \mathrm{O}+\mathrm{H}$ & $1.170 \mathrm{E}+09$ & $1.300 \mathrm{E}+00$ & $1.517 E+01$ \\
\hline $\mathrm{r} 2 \mathrm{~b}$ & $\mathrm{H}_{2}+\mathrm{OH}=\mathrm{H}_{2} \mathrm{O}+\mathrm{H}$ & $7.980 \mathrm{E}+10$ & $9.726 \mathrm{E}-01$ & $8.200 E+01$ \\
\hline r3f & $\mathrm{H}+\mathrm{O}_{2}=\mathrm{OH}+\mathrm{O}$ & $2.000 \mathrm{E}+14$ & $0.000 \mathrm{E}+00$ & $7.029 E+01$ \\
\hline $\mathrm{r} 3 \mathrm{~b}$ & $\mathrm{H}+\mathrm{O}_{2}=\mathrm{OH}+\mathrm{O}$ & $6.712 \mathrm{E}+11$ & $3.742 \mathrm{E}-01$ & $-1.190 \mathrm{E}+00$ \\
\hline $\mathrm{r} 4 \mathrm{f}$ & $\mathrm{O}+\mathrm{H}_{2}=\mathrm{OH}+\mathrm{H}$ & $1.800 \mathrm{E}+10$ & $1.000 \mathrm{E}+00$ & $3.693 \mathrm{E}+01$ \\
\hline $\mathrm{r} 4 \mathrm{~b}$ & $\mathrm{O}+\mathrm{H}_{2}=\mathrm{OH}+\mathrm{H}$ & $7.014 \mathrm{E}+09$ & $1.014 \mathrm{E}+00$ & $2.866 \mathrm{E}+01$ \\
\hline $\mathrm{r} 5 \mathrm{f}$ & $\mathrm{H}+\mathrm{O}_{2}+\mathrm{M}_{1}=\mathrm{HO}_{2}+\mathrm{M}_{1}$ & $2.100 \mathrm{E}+18$ & $-1.000 \mathrm{E}+00$ & $0.000 \mathrm{E}+00$ \\
\hline $\mathrm{r} 5 \mathrm{~b}$ & $\mathrm{H}+\mathrm{O}_{2}+\mathrm{M}_{1}=\mathrm{HO}_{2}+\mathrm{M}_{1}$ & $6.276 \mathrm{E}+20$ & $-1.660 \mathrm{E}+00$ & $2.142 E+02$ \\
\hline r6f & $\mathrm{H}+2 \mathrm{O}_{2}=\mathrm{HO}_{2}+\mathrm{O}_{2}$ & $6.700 \mathrm{E}+19$ & $-1.420 \mathrm{E}+00$ & $0.000 \mathrm{E}+00$ \\
\hline $\mathrm{r} 6 \mathrm{~b}$ & $\mathrm{H}+2 \mathrm{O}_{2}=\mathrm{HO}_{2}+\mathrm{O}_{2}$ & $2.002 E+22$ & $-2.080 \mathrm{E}+00$ & $2.142 E+02$ \\
\hline$r 7 f$ & $\mathrm{H}+\mathrm{O}_{2}+\mathrm{N}_{2}=\mathrm{HO}_{2}+\mathrm{N}_{2}$ & $6.700 E+19$ & $-1.420 \mathrm{E}+00$ & $0.000 \mathrm{E}+00$ \\
\hline $\mathrm{r} 7 \mathrm{~b}$ & $\mathrm{H}+\mathrm{O}_{2}+\mathrm{N}_{2}=\mathrm{HO}_{2}+\mathrm{N}_{2}$ & $2.002 E+22$ & $-2.080 \mathrm{E}+00$ & $2.142 E+02$ \\
\hline r8f & $\mathrm{OH}+\mathrm{HO}_{2}=\mathrm{H}_{2} \mathrm{O}+\mathrm{O}_{2}$ & $5.000 \mathrm{E}+13$ & $0.000 \mathrm{E}+00$ & $4.184 \mathrm{E}+00$ \\
\hline $\mathrm{r} 8 \mathrm{~b}$ & $\mathrm{OH}+\mathrm{HO}_{2}=\mathrm{H}_{2} \mathrm{O}+\mathrm{O}_{2}$ & $4.033 \mathrm{E}+14$ & $7.798 \mathrm{E}-02$ & $2.972 \mathrm{E}+02$ \\
\hline r9f & $\mathrm{H}+\mathrm{HO}_{2}=2 \mathrm{OH}$ & $2.500 E+14$ & $0.000 \mathrm{E}+00$ & $7.950 \mathrm{E}+00$ \\
\hline $\mathrm{r} 9 \mathrm{~b}$ & $\mathrm{H}+\mathrm{HO}_{2}=2 \mathrm{OH}$ & $3.867 \mathrm{E}+10$ & $7.930 \mathrm{E}-01$ & $1.544 \mathrm{E}+02$ \\
\hline r10f & $\mathrm{O}+\mathrm{HO}_{2}=\mathrm{O}_{2}+\mathrm{OH}$ & $4.800 \mathrm{E}+13$ & $0.000 \mathrm{E}+00$ & $4.184 \mathrm{E}+00$ \\
\hline $\mathrm{r} 10 \mathrm{~b}$ & $\mathrm{O}+\mathrm{HO}_{2}=\mathrm{O}_{2}+\mathrm{OH}$ & $2.212 \mathrm{E}+12$ & $4.189 \mathrm{E}-01$ & $2.221 \mathrm{E}+02$ \\
\hline $\mathrm{r} 11 \mathrm{f}$ & $2 \mathrm{OH}=\mathrm{O}+\mathrm{H}_{2} \mathrm{O}$ & $6.000 \mathrm{E}+08$ & $1.300 \mathrm{E}+00$ & $0.000 \mathrm{E}+00$ \\
\hline $\mathrm{r} 11 \mathrm{~b}$ & $2 \mathrm{OH}=\mathrm{O}+\mathrm{H}_{2} \mathrm{O}$ & $1.050 \mathrm{E}+11$ & $9.591 \mathrm{E}-01$ & $7.510 \mathrm{E}+01$ \\
\hline $\mathrm{r} 12 \mathrm{f}$ & $\mathrm{H}_{2}+\mathrm{M}_{2}=2 \mathrm{H}+\mathrm{M}_{2}$ & $2.230 \mathrm{E}+12$ & $5.000 \mathrm{E}-01$ & $3.874 \mathrm{E}+02$ \\
\hline $\mathrm{r} 12 \mathrm{~b}$ & $\mathrm{H}_{2}+\mathrm{M}_{2}=2 \mathrm{H}+\mathrm{M}_{2}$ & $6.310 \mathrm{E}+10$ & $7.542 \mathrm{E}-01$ & $-5.301 \mathrm{E}+01$ \\
\hline $\mathrm{r} 13 \mathrm{f}$ & $\mathrm{O}_{2}+\mathrm{M}=2 \mathrm{O}+\mathrm{M}$ & $1.850 \mathrm{E}+11$ & $5.000 \mathrm{E}-01$ & $3.998 \mathrm{E}+02$ \\
\hline $\mathrm{r} 13 \mathrm{~b}$ & $\mathrm{O}_{2}+\mathrm{M}=2 \mathrm{O}+\mathrm{M}$ & $4.508 \mathrm{E}+07$ & $1.115 \mathrm{E}+00$ & $-1.038 \mathrm{E}+02$ \\
\hline $\mathrm{r} 14 \mathrm{f}$ & $\mathrm{H}+\mathrm{OH}+\mathrm{M}_{3}=\mathrm{H}_{2} \mathrm{O}+\mathrm{M}_{3}$ & $7.500 E+23$ & $-2.600 \mathrm{E}+00$ & $0.000 \mathrm{E}+00$ \\
\hline $\mathrm{r} 14 \mathrm{~b}$ & $\mathrm{H}+\mathrm{OH}+\mathrm{M}_{3}=\mathrm{H}_{2} \mathrm{O}+\mathrm{M}_{3}$ & $1.808 \mathrm{E}+27$ & $-3.182 E+00$ & $5.073 E+02$ \\
\hline $\mathrm{r} 15 \mathrm{f}$ & $\mathrm{H}+\mathrm{HO}_{2}=\mathrm{H}_{2}+\mathrm{O}_{2}$ & $2.500 E+13$ & $0.000 \mathrm{E}+00$ & $2.929 E+00$ \\
\hline $\mathrm{r} 15 \mathrm{~b}$ & $\mathrm{H}+\mathrm{HO}_{2}=\mathrm{H}_{2}+\mathrm{O}_{2}$ & $2.956 \mathrm{E}+12$ & $4.053 \mathrm{E}-01$ & $2.292 E+02$ \\
\hline $\mathrm{r} 16 \mathrm{f}$ & $2 \mathrm{HO}_{2}=\mathrm{H}_{2} \mathrm{O}_{2}+\mathrm{O}_{2}$ & $2.000 \mathrm{E}+12$ & $0.000 \mathrm{E}+00$ & $0.000 E+00$ \\
\hline $\mathrm{r} 16 \mathrm{~b}$ & $2 \mathrm{HO}_{2}=\mathrm{H}_{2} \mathrm{O}_{2}+\mathrm{O}_{2}$ & $5.131 E+13$ & $-1.776 \mathrm{E}-01$ & $1.553 \mathrm{E}+02$ \\
\hline $\mathrm{r} 17 \mathrm{f}$ & $\mathrm{H}_{2} \mathrm{O}_{2}+\mathrm{M}=2 \mathrm{OH}+\mathrm{M}$ & $1.300 \mathrm{E}+17$ & $0.000 \mathrm{E}+00$ & $1.904 \mathrm{E}+02$ \\
\hline $\mathrm{r} 17 \mathrm{~b}$ & $\mathrm{H}_{2} \mathrm{O}_{2}+\mathrm{M}=2 \mathrm{OH}+\mathrm{M}$ & $2.622 \mathrm{E}+09$ & $1.630 \mathrm{E}+00$ & $-3.268 \mathrm{E}+01$ \\
\hline $\mathrm{r} 18 \mathrm{f}$ & $\mathrm{H}_{2} \mathrm{O}_{2}+\mathrm{H}=\mathrm{HO}_{2}+\mathrm{H}_{2}$ & $1.600 \mathrm{E}+12$ & $0.000 \mathrm{E}+00$ & $1.590 \mathrm{E}+01$ \\
\hline $\mathrm{r} 18 \mathrm{~b}$ & $\mathrm{H}_{2} \mathrm{O}_{2}+\mathrm{H}=\mathrm{HO}_{2}+\mathrm{H}_{2}$ & $7.375 E+09$ & $5.829 \mathrm{E}-01$ & $8.682 E+01$ \\
\hline r19f & $\mathrm{H}_{2} \mathrm{O}_{2}+\mathrm{OH}=\mathrm{H}_{2} \mathrm{O}+\mathrm{HO}_{2}$ & $1.000 \mathrm{E}+13$ & $0.000 \mathrm{E}+00$ & $7.531 E+00$ \\
\hline $\mathrm{r} 19 \mathrm{~b}$ & $\mathrm{H}_{2} \mathrm{O}_{2}+\mathrm{OH}=\mathrm{H}_{2} \mathrm{O}+\mathrm{HO}_{2}$ & $3.144 \mathrm{E}+12$ & $2.556 \mathrm{E}-01$ & $1.453 \mathrm{E}+02$ \\
\hline
\end{tabular}

Reaction 
$\mathrm{s}_{\mathrm{i}}^{\mathrm{t}}=\mathrm{s}_{\mathrm{i}}^{\mathrm{l}} \frac{\tau_{\mathrm{kin}}}{\tau_{\mathrm{kin}}+f \cdot \tau_{\text {turb }}}$

Where

$\tau_{\text {turb }}=C \cdot \frac{K}{\varepsilon}$

And

$f=\frac{1-\exp (-r)}{0.632}$

$r=\frac{m_{\mathrm{H}_{2} \mathrm{O}}+m_{\mathrm{H}_{2}}}{1-m_{\mathrm{N}_{2}}}$

Default values are used for the all the constants involved in STAR-CCM. Initial and boundary conditions are obtained by using CAE simulations. No tuning of the model is considered. Numeric may have an influence on the computational results, especially the grid size, because the flow domain, that is made up of in-cylinder, pre-chamber and fuel injector, may have very different characteristic sizes in different locations (an engine bore is $100 \mathrm{~mm}$, while the maximum needle lift of a piezo GDI injector is $0.04 \mathrm{~mm}$ ), and therefore achievement of grid-independent solutions could be troublesome. For sake of simplicity and unavailability of validation data on the specific configuration, the influence of numeric is currently neglected.

\section{Results and discussion}

CFD simulations have been performed first for the standalone pre-chamber connected to a simplified main chamber where constant pressure outlet boundary conditions apply. The computational domain is made up of the jet ignition prechamber volume, plus a downstream semi spherical volume where the pressure outlet boundary condition is enforced. Inlet boundary condition is used at the entry of the injector sac volume, where fuel velocity, temperature, turbulent intensity and length scale are prescribed. The inlet velocity is set to introduce a prescribed amount of fuel within a prescribed injection time using a triangular profile (the opening time does not allow to reach full opening of the needle). The prescribed inlet velocity does not produce sonic conditions through the nozzles. All the other boundaries of the domain are constant temperature walls. The computational grid is made up of 450,000 polyhedral cells, with 2,800,000 faces and 2,700,000 vertices. Modelling of the injector interior makes minimum mesh sizes very small. Integration in time is implicit with time steps of the order of $10^{-2} \mathrm{~ms}$ while minimum mesh sizes approaches a few $\mu \mathrm{m}$.

Computations have been performed with a temperature of $1300 \mathrm{~K}$ prescribed for the glow plug surface and a temperature of $550 \mathrm{~K}$ prescribed for all the other surfaces of the prechamber. Inlet fuel temperature is $300 \mathrm{~K}$, outlet pressure is 50 bar. Initial conditions are pressure 50 bar and temperature $950 \mathrm{~K}$ and no flow. The amount of hydrogen introduced is $0.3 \mathrm{mg}$, corresponding to a $\lambda=3$ operation. Actual sac volume and diameter of nozzles of the multi holes injector are much smaller than the dimensions shown. Fig. 2 presents computed results 0.25 ms after start of injection for mass fractions of $\mathrm{H}_{2}$, $\mathrm{OH}$ and $\mathrm{H}_{2} \mathrm{O}$. Flow from nozzles impinges on glow plug or pre-
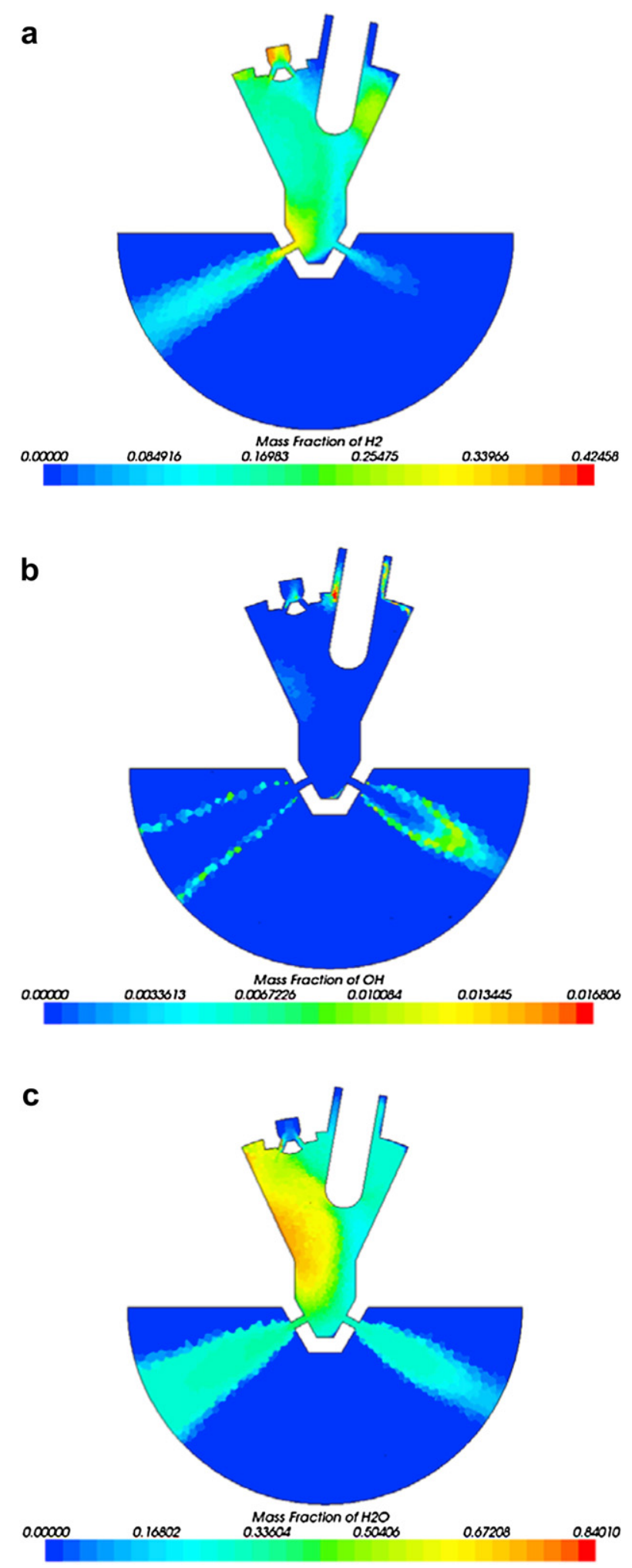

Fig. 2 - Mass fractions $0.25 \mathrm{~ms}$ after start of injection: a. $\mathrm{H}_{2}$; b. $\mathrm{OH} ;$ c. $\mathrm{H}_{2} \mathrm{O}$.

chamber walls almost immediately. Then, the most of the fuel starts to move downstream along the pre-chamber walls, while the fuel about the glow plug starts combustion shortly after impingement on the hot glow plug surface and 
subsequent diffusion in the surrounding hot air. Combustion starts in the high temperature region close to the glow plug where temperatures are sufficiently high and the composition of the mixture is adequate. After combustion is started, combustion occurs after impingement of the cold fuel jet with the pre-chamber walls or the glow plug and the subsequent diffusion in the hot air. As a result of the combustion evolution, energy being released increases the temperature of the remaining fuel and air thus increasing the rate of combustion, also boosted by multiplication of areas where combustion occurs because of the propagating flame front. As soon as the combustion within the pre-chamber proceeds to a significant extent, unburned fuel, incomplete and complete combustion products are transferred to the main chamber.

A sensitivity analysis has been performed on the initial and boundary conditions. This sensitivity analysis has been minimal in consideration of the neglected unsteady flow from the main chamber that is also supposed to have a strong influence. The previous description of the pre-chamber operation changes if the temperatures are modified, because the process is mainly controlled by kinetics. The initial temperature is the most important parameter. Glow plug temperature also has a major effect. The glow plug temperature strongly influences the initial temperature of air when the pre-chamber is fitted to the engine. Adjusting the glow plug temperature, and therefore the air temperature within the pre-chamber, it could be possible to tune auto ignition to particular load and speed operating points. Inlet fuel velocity, and therefore velocity of jets issuing from the injector nozzles, and amount of fuel introduced also play a role. Major results of these computations are the time scales for injection duration and release of heat within the pre-chamber, being respectively $0.3-0.4 \mathrm{~ms}$ and $0.1 \mathrm{~ms}$ during the sensitivity analysis. The influence of mesh size and shape on the computed results is presently neglected.

CFD injection and combustion simulations have then been performed for a single engine cylinder of a larger 3.6 L, naturally aspirated six cylinders, gasoline engine fuelled with hydrogen. This engine has $V_{D}=600 \mathrm{~cm}^{3}, V_{P C}=1.5 \mathrm{~cm}^{3}$, $\mathrm{CR}=10.8$ and $\mathrm{CR}^{*}=11.0$. Computations start at intake valve closure when initial conditions are set by using results of CAE engine simulations, and end at exhaust valve opening. Piston moves following the compression and expansion strokes, and the computational domain made up of the in-cylinder volume contract or expands accordingly, while layers are added and removed. The computational grid, made up of 300,000 polyhedral cells to keep the computational time and the internal memory requirements low. Morphing is used to change the grid density to the variable in-cylinder space aiming to produce computationally effective mesh elements in size and shape. Main chamber and pre-chamber injections are performed with very basic single holes injectors where up to sonic velocity is set during injector opening times. Simulations have been performed neglecting the residual gases within the cylinder and the pre-chamber at intake valve closure. The main chamber injector maximum flow area is 2.25 times larger than the pre-chamber injector maximum flow area and operates higher pressure.

Computations have been performed with a glow plug temperature of $1200 \mathrm{~K}$ for operation with air-to-fuel equivalent ratio $\lambda=2.25$ for both the main chamber and the pre-chamber and an engine speed of $7500 \mathrm{rpm}$. This high speed test is quite difficult for auto ignition engines (Diesel engines are well known being unable to run engine speed exceeding $4500 \mathrm{rpm}$ because of diffusion and kinetics controlled Diesel combustion). The start of injection (SOI) for the main chamber injector is $40^{\circ} \mathrm{crank}$ angle before top dead centre (TDC), while the end of injection (EOI) is located $5^{\circ}$ crank angle after TDC. The SOI for the pre-chamber injector is $20^{\circ}$ crank angle before TDC, and EOI is located at $5^{\circ} \mathrm{crank}$ angle after TDC. Fig. 3 presents the computed temperature fields within the in-cylinder at different crank angle positions about firing top dead centre. Interval between pictures is $2^{\circ}$ crank angle or $4.44 \times 10^{-5} \mathrm{~s}$. Following injection, combustion starts almost immediately in hot spots with fuel available about the glow plug, but it takes a finite time to have a considerable flamed volume and therefore a significant heat
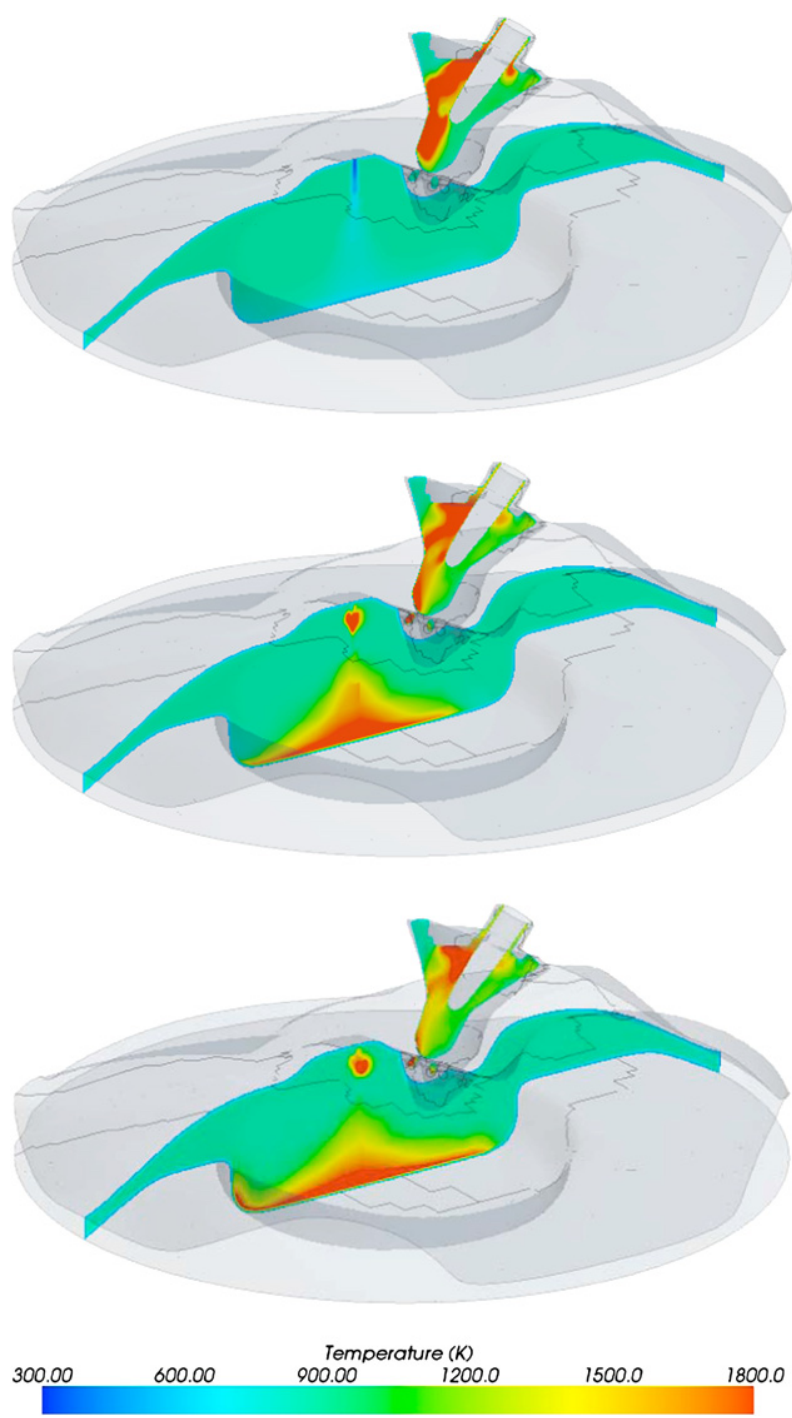

Fig. 3 - Computed temperature fields within the cylinder of the DI-JI engine in the glow plug version about TDC with intervals of $2^{\circ}$ crank angle or $4.44 \cdot 10^{-5} \mathrm{~s}(\lambda=2.25$, $N=7500 \mathrm{rpm})$. 

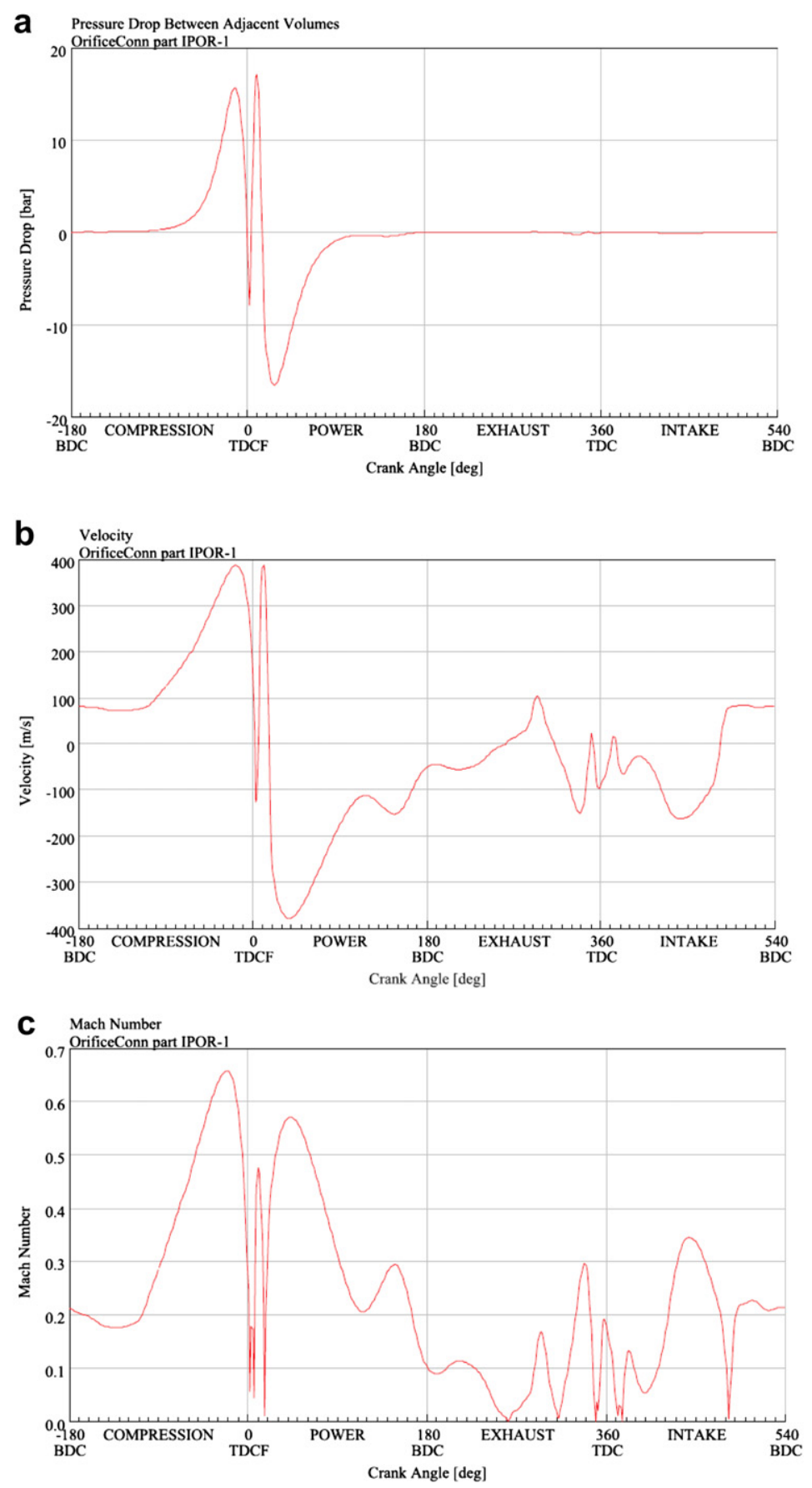

Fig. 4 - Flow parameters across the pre-chamber to main chamber nozzles $(1=2.25, \mathrm{~N}=7500$ rpm): a. pressure drop; b. velocity ; c. Mach number.

released within the pre-chamber, during which the fuel may continue to enter the pre-chamber. The strong flow from the main chamber following the compression stroke pushes the gases starting combustion towards the top of the pre-chamber. When a significant quantity of fuel within the pre-chamber is burned or combusting, then combustion quickly propagates to the rest of the pre-chamber volume. Finally, when combustion within the pre-chamber is fully initiated, the jet of partially combusted, hot products then rapidly spread combustion all over the main chamber through multiple jets, with help from the expansion stroke that contributes to the flow prechamber to main chamber. Combustion within the main chamber then completes within a very short time despite of the lean composition, because almost all the fuel is located behind the jet ignition nozzles. Even if the combustion event within the main chamber occurs quickly, thanks to the lean burn operation temperatures are still low to keep low the production of oxides of nitrogen. Because combustion occurs in a central area fully ignited by the pre-chamber jets, there is no fuel escaping combustion. 

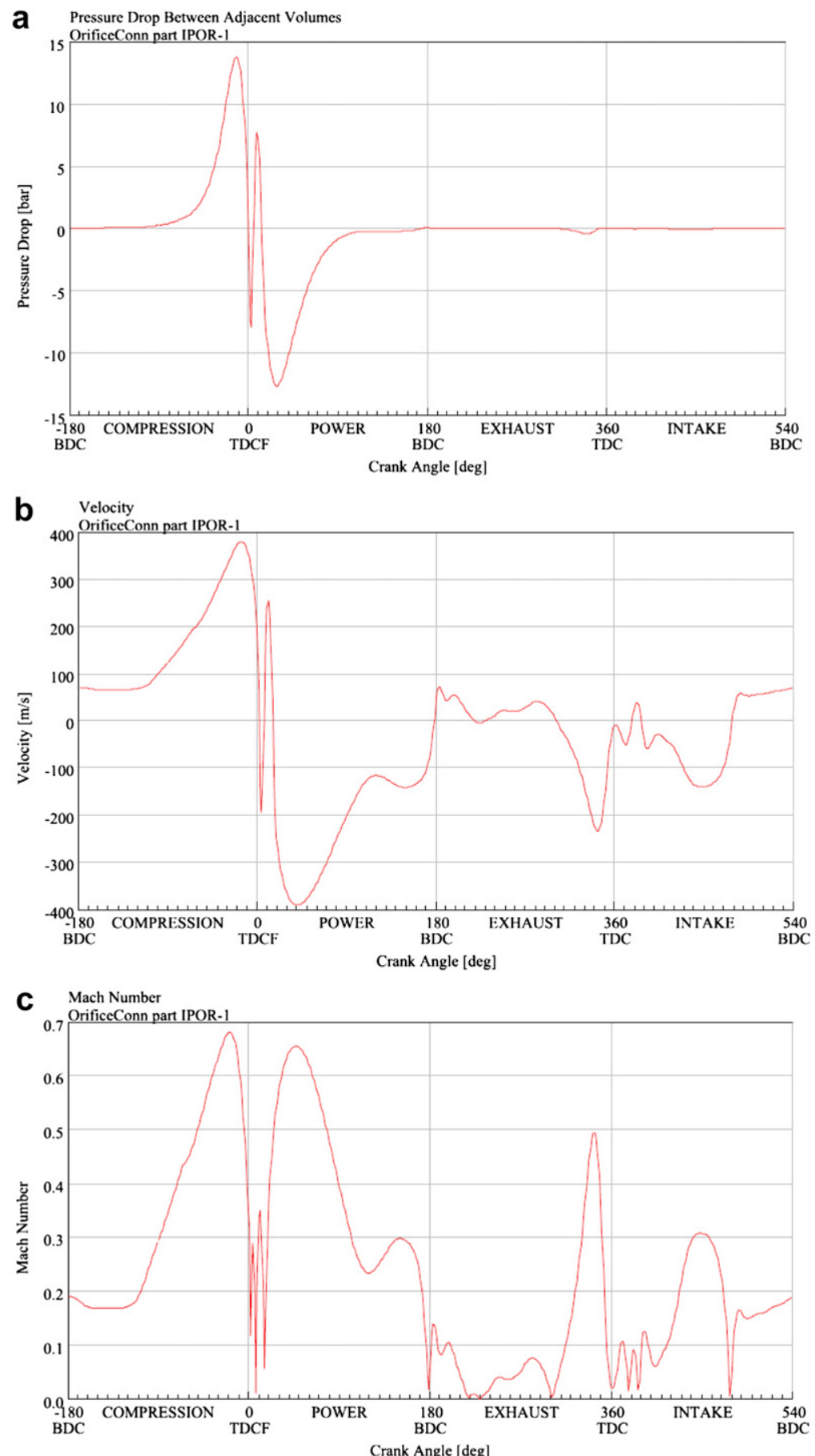

Fig. 5 - Flow parameters across the pre-chamber to main chamber nozzles $(l=4.5, N=7500 \mathrm{rpm})$ : $a$. pressure drop; b. velocity ; c. Mach number.

These results provide further details of the operation of the pre-chamber in the auto ignition mode, and also give an update of time scales for CAE engine performance simulations. The time scales for injection duration are slightly larger than what previously guessed, up to $0.4-0.45 \mathrm{~ms}$, while the time scale for the heat release within the pre-chamber remains close to $0.1 \mathrm{~ms}$. The glow plug temperature is reduced, but there is more time to transfer heat from the glow plug to the surrounding area. However, fresh air is drawn into the pre-chamber from the main chamber during the compression stroke, and the flow field is very intense even before injection. The time scale for the evolution of combustion within the main chamber is now close to $0.25 \mathrm{~ms}$, with combustion duration $10-90 \%$ of approximately $10^{\circ} \mathrm{crank}$ angle. The influence of mesh size and shape on the computed results is presently neglected. 
CAE engine simulations have been finally performed by using these time scales for injection duration and release of heat within the pre-chamber and main chamber. In these computations, the ignition pre-chambers are fitted on the cylinder head of a small high-tech four cylinders, $1.5 \mathrm{~L}$, highly turbocharged engine having $\mathrm{V}_{\mathrm{D}}=375 \mathrm{~cm}^{3}, \mathrm{~V}_{\mathrm{PC}}=1.5 \mathrm{~cm}^{3}$, $\mathrm{CR}=13.8$ and $\mathrm{CR}^{*}=14.5$ better described in [11-16]. The prechamber is modeled as a volume connected to the main chamber through orifices. Fluid is injected and chemical reactions occur within the pre-chamber. Fuel rails are modeled, as well the two injectors towards pre-chamber and main chamber. These two injectors are modeled as volumes connected respectively to the main chamber and the prechamber through orifices, and connected to their feeding rail through a passage area prescribed in time. The pre-chamber direct injector injects the fuel close to TDC to produce the jet ignition of the main chamber fuel immediately following the firing TDC. The SOI for the pre-chamber injector is $25^{\circ} \mathrm{crank}$ angle before TDC, and EOI is also located at TDC. During fuel injection within the pre-chamber, occurrence of combustion is neglected. After an ignition delay period taken equal to the injection event, reactants within the pre-chamber are removed in stoichiometric proportions and replaced by hot products. This process is supposed to complete within $0.1 \mathrm{~ms}$. The main chamber combustion is finally supposed to occur within a prescribed time frame (Wiebe function with combustion duration $10-90 \%$ of about $10^{\circ}$ crank angle).

Results presented in Figs. 4 and 5 refer to operation of the engine with main chamber $\lambda=2.25$ and $\lambda=4.5$ at engine speed $N=7500 \mathrm{rpm}$. The start of injection (SOI) for the main chamber injector is respectively $45^{\circ}$ and $30^{\circ} \mathrm{crank}$ angle before top dead centre (TDC), while the end of injection (EOI) is located at TDC. These Figures present pressure drop, velocity and Mach Number through the nozzles connecting the prechamber to the main chamber. During the compression stroke, pressure in the main chamber is larger than the pressure in the pre-chamber, and flow of air and residuals is moving from the main chamber to the pre-chamber. Towards the end of the compression stroke, injection occurs within the main chamber and the pre-chamber. Ignition is placed at TDC. After TDC, pre-chamber and main chamber injections end. The addition of hot products in the pre-chamber produces a higher pressure in the pre-chamber than in the main chamber. The flow from the pre-chamber to the main chamber then lowers the pressure within the pre-chamber. Combustion finally starts in the main chamber. As soon as the combustion in the main chamber proceeds, pressure in the main chamber becomes again larger than the pressure in the pre-chamber and the flow returns to be from the main chamber to the pre-chamber. During the power stoke, the effect of the increased volume due to the piston motion shortly exceeds the effect of the heat release, the pressure within the main chamber falls below the pre-chamber pressure and the flow is again from the pre-chamber to the main chamber up to the end of the power stroke. The quantity of unburned fuel trapped within the pre-chamber is negligible. Reducing the amount of main chamber fuel running leaner reduces the flow main chamber to pre-chamber following combustion in the main chamber, with the other main features of pre-chamber operation virtually unchanged.

\section{Conclusions}

Jet ignition pre-chambers are enablers of very fast ignition and combustion of main chamber mixtures. Their evolution is central to the development of the always lean burn direct injection jet ignition engine aimed at increased top brake efficiencies and reduced penalties changing the load. A first detailed description of the operation of a spark-less jet ignition pre-chamber has been provided in the paper.

The complex operation of the pre-chamber and the incylinder, including mixture formation, auto ignition, prechamber combustion evolution, jet ignition of the main chamber mixture and main chamber combustion evolution has been described using detailed chemistry libraries coupled to turbulent flow computations. Use of the STAR-CCM CFD code coupled with the DARS chemical package has proved to be fast and reliable permitting user to focus on the application rather that in the details of chemistry or turbulence.

The injection process within the pre-chamber should occur within 0.3-0.4 ms depending on the boost of the engine. Following auto ignition of a significant fraction of the fuel within the pre-chamber, and significant release of fuel energy, the combustion process within the pre-chamber then evolves very quickly producing multiple jet of hot partial combustion products towards the main chamber over $0.1 \mathrm{~ms}$. The combustion evolution within the main chamber is then much faster than with spark plug ignition, with combustion angles $10-90 \%$ of about $10^{\circ}$ running $7500 \mathrm{rpm}$.

CFD simulations integrated with CAE engine performance simulations have provided guidelines for selection of prechamber and main chamber fuel injectors and glow plug. Assembly of a prototype always lean burn direct injection jet ignition engine running hydrogen fuel appears to be possible by using off-the-shelf components for glow plug and direct injectors, even if some changes are needed especially in the tip area of the injectors to better exploit the advantages of the concept.

This work still in progress is aimed at reducing and capturing emissions in transport and energy generation. Benefits of the technology includes reduced greenhouse and other emissions and reduced consumption as well as encourage the increased uptake of alternative fuels, thus potentially enhancing national energy security and reducing greenhouse gas emissions.

\section{Acknowledgements}

Author wishes to thank Peter Ewing of VETA Pty Ltd and CDadapco Australia and Angelo Tempia of Robert Bosch (Australia) Pty Ltd for the support provided.

\section{R E F E R E N C E S}

[1] White CM, Steeper RR, Lutz AE. The hydrogen-fueled internal combustion engine: a technical review. International Journal of Hydrogen Energy August 2006;31(10):1292-305. 
[2] Knop Vincent, Benkenida Adlène, Jay Stéphane, Colin Olivier. Modelling of combustion and nitrogen oxide formation in hydrogen-fuelled internal combustion engines within a 3D CFD code. International Journal of Hydrogen Energy October 2008;33(19):5083-97.

[3] Verhelst S, Maesschalck P, Rombaut N, Sierens R. Increasing the power output of hydrogen internal combustion engines by means of supercharging and exhaust gas recirculation. International Journal of Hydrogen Energy May 2009;34(10): 4406-12.

[4] Mohammadi Ali, Shioji Masahiro, Nakai Yasuyuki, Ishikura Wataru, Tabo Eizo. Performance and combustion characteristics of a direct injection SI hydrogen engine. International Journal of Hydrogen Energy February 2007; 32(2):296-304.

[5] Boretti Alberto A, Watson Harry C. Enhanced combustion by jet ignition in a turbocharged cryogenic port fuel injected hydrogen engine. International Journal of Hydrogen Energy March 2009;34(5):2511-6.

[6] Safari H, Jazayeri SA, Ebrahimi R. Potentials of NOX emission reduction methods in SI hydrogen engines: simulation study. International Journal of Hydrogen Energy January 2009;34(2): 1015-25.

[7] D'Errico Gianluca, Onorati Angelo, Ellgas Simon. 1D thermofluid dynamic modelling of an S.I. single-cylinder $\mathrm{H}_{2}$ engine with cryogenic port injection. International Journal of Hydrogen Energy October 2008;33(20):5829-41.

[8] Kawahara Nobuyuki, Tomita Eiji. Visualization of autoignition and pressure wave during knocking in a hydrogen spark-ignition engine. International Journal of Hydrogen Energy April 2009;34(7):3156-63.

[9] Gomes Antunes JM, Mikalsen R, Roskilly AP. An experimental study of a direct injection compression ignition hydrogen engine. International Journal of Hydrogen Energy August 2009;34(15):6516-22.

[10] Jonathan Nieminen, Ninochka D'Souza, Ibrahim Dincer. "Comparative combustion characteristics of gasoline and hydrogen fuelled ICEs". International Journal of Hydrogen Energy, Corrected Proof, Available online. 2 October 2009, in press., doi:10.1016/j.ijhydene.2009.08.098.

[11] A.A. Boretti, H.C. Watson. "Development of a direct injection high efficiency liquid phase LPG spark ignition engine". Paper presented to the SAE 2009 International Power trains, Fuels and Lubricants Meeting. Florence, Italy; June 15-17, 2009. SAE P. 2009-01-1881.

[12] A.A. Boretti, H.C. Watson. "Development of a direct injection high flexibility CNG/LPG spark ignition engine". Paper presented to the SAE 2009 International Power trains, Fuels and Lubricants Meeting. Florence, Italy; June 15-17, 2009. SAE P. 2009-01-1969.

[13] A.A. Boretti, H.C. Watson. "The lean burn direct-injection jetignition turbocharged liquid phase LPG engine". Paper presented to the 15th Asia Pacific Automotive Engineering Conference (APAC-15). Hanoi, Vietnam; October 2009.

[14] Boretti AA, Watson HC. The lean burn direct-injection jetignition gas engine. International Journal of Hydrogen Energy 2009;34:7835-41.

[15] A.A. Boretti, H.C. Watson. "The lean burn direct-injection jetignition flexi gas fuel LPG/CNG engine". Paper presented to the 2009 SAE Power trains, Fuels and Lubricants Meeting. San Antonio, Texas, USA; November 2009. SAE P. 2009-012790.

[16] Boretti AA, Watson HC, Tempia A. Computational analysis of the lean burn direct-injection jet-ignition hydrogen engine.
Proceedings of the Institution of Mechanical Engineers Part D Journal of Automobile Engineering 2009;224:261-9.

[17] Mastorakos Epaminondas. Ignition of turbulent nonpremixed flames. Progress in Energy and Combustion Science 2009;35:57-97.

[18] Echekki Tarek. Stochastic modeling of autoignition in turbulent nonhomogeneous hydrogen-air mixtures. International Journal of Hydrogen Energy 2008;33:2596-603.

[19] Xu BP, El Hima L, Wen JX, Dembele S, Tam VHY, Donchev T. Numerical study on the spontaneous ignition of pressurized hydrogen release through a tube into air. Journal of Loss Prevention in the Process Industries 2008;21:205-13.

[20] Yamada Eisuke, Watanabe Satoru, Koichi Hayashi A, Tsuboi Nobuyuki. Numerical analysis on auto-ignition of a high pressure hydrogen jet spouting from a tube. Proceedings of the Combustion Institute 2009;32:2363-9.

[21] Oevermann M, Schmidt H, Kerstein AR. Investigation of autoignition under thermal stratification using linear eddy modelling. Combustion and Flame 2008;155:370-9.

[22] Andac MG, Egolfopoulos FN. Diffusion and kinetics effects on the ignition of premixed and non-premixed flames. Proceedings of the Combustion Institute 2007;31:1165-72.

[23] Herzler J, Naumann C. Shock-tube study of the ignition of methane/ethane/hydrogen mixtures with hydrogen contents from 0 to $100 \%$ at different pressures. Proceedings of the Combustion Institute 2009;32:213-20.

[24] Gersena S, Anikina NB, Mokhova AV, Levinskya HB. Ignition properties of methane/hydrogen mixtures in a rapid compression machine. International Journal of Hydrogen Energy 2008;33:1957-64.

[25] NicoleDonato S, EricPetersen L. Simplified correlation models for $\mathrm{CO} / \mathrm{H}_{2}$ chemical reaction times. International Journal of Hydrogen Energy 2008;33:7565-79.

[26] http://delphi.com/shared/pdf/ppd/pwrtrn/gas_multec_ gdifsc.pdf [retrieved 25.01.09].

[27] http://www.conti-online.com/generator/www/de/en/ continental/automotive/general/press_service/press releases/hidden/powertrain/pr_2008_04_25_piezo_ngi_en. $\mathrm{html}$ [retrieved 25.01.09].

[28] http://www.hoerbiger.com/Niche-Automotive-Applications. 10762.0.html [retrieved 25.01.09].

[29] http://www.cd-adapco.com/products/STAR-CCM_plus/ index.html [retrieved 25.01.09].

[30] http://www.gtisoft.com/applications/a_Engine_Performance. php [retrieved 25.01.09].

[31] Meeks Ellen. Strategies for incorporating detailed kinetics into engine simulation, Future fuels for IC engines. Madison, WI: ERC 2007 Symposium, http://www.erc.wisc.edu/documents/ symp07-Meeks.pdf; June 6-7, 2007 [retrieved 25.01.09]

[32] Lehtiniemi Harry. Efficient engine CFD with detailed chemistry, Future fuels for IC engines. Madison, WI: ERC 2007 Symposium, http://www.erc.wisc.edu/documents/symp07Lehtiniemi.pdf; June 6-7, 2007 [retrieved 25.01.09].

[33] http://www.diganars.com/about.html [retrieved 25.01.09].

[34] Williams Forman A. Detailed and reduced chemistry for hydrogen autoignition. Journal of Loss Prevention in the Process Industries 2008;21:131-5.

[35] Konnov Alexander A. Remaining uncertainties in the kinetic mechanism of hydrogen combustion. Combustion and Flame 2008;152:507-28.

[36] Conaire Marcus Ó, Curran Henry J, Simmie John M, Pitz William J, Westbrook Charles K. A comprehensive modeling study of hydrogen oxidation. Published online in Wiley InterScience, www.interscience.wiley.com. 